\title{
A Comparative Analysis of the Cultural Content in Go For It and New Standard English
}

\author{
Yujie Shi \\ Yanbian University, Yanji, Jilin Province, China \\ Xuebo Cui \\ Yanbian University, Yanji, Jilin Province, China
}

\begin{abstract}
With the development of globalization, more and more attention has been paid to the cultivation of cross-cultural awareness in English learning. Based on the English Curriculum Standard for compulsory Education (2011), this paper analyzes the cultural content of middle school English materials in "Go For It" and "New Standard English". Through the comparison of two sets of materials and the investigation of students, this paper sums up the advantages and improvements of two materials, which can provide a reference for the compilation of cultural content and help English teachers' cultural teaching to enhance students' cultural awareness.
\end{abstract}

Index Terms-middle school, English materials, cultural content

\section{INTRODUCTION}

By looking up the relevant literature, we find that the analysis of cultural content of English materials is mostly aimed at senior high school and college, and there is little analysis of the cultural content of middle school materials. With the development of globalization, more and more attention has been paid to the cultivation of international perspective in English learning. By comparing the cultural content of the two materials, we can find out advantages and improvements of the two materials, which can be used for reference in the compilation of the cultural contents in materials and also provides for teachers' cultural teaching to cultivate students' cultural awareness.

\section{LITERATURE REVIEW}

\section{A. Definition and Classification of Culture}

1. Definition of culture

Culture is an extremely complicated social phenomenon. From ancient to present, many anthropologists have tried to define culture accurately.

The famous English anthropologist Tylor (1871) wrote in "Primitive Culture", stated that "Culture becomes civilization, in its broad ethnographic sense, including knowledge, faith, art, morality, law". In Tylor's view, culture is a whole of all fields. According to the definition of culture in the English Curriculum Standard for compulsory Education (2011), it is stated that "Culture refers to the history, geography, local customs, traditional customs, way of life, standard of behavior, literature, art and values of the countries in which they have learned the language." It is important to note that culture should not only be British and American culture, but also the culture of other countries in the world.

2. Classification of culture

H.Stern divides culture into broad and narrow terms according to the structure and category of culture. Generalized Culture is Capital Culture (Culture with a big C), narrow sense Culture is lowercase Culture (Culture with a small c).

Wang Fei (2010) said that "Culture can be divided into target culture (British and American culture, other English-speaking culture), native culture, comparative culture (comparison between two or more cultures), culture of non-English-speaking countries". It is suggested that the authors should incorporate different types of cultures into the content of the materials flexibly. According to the classification of Wang Fei, the author analyzed two sets of materials on cultural content.

\section{B. The Importance of Cultural Content in Materials}

\section{Spread the excellent culture of our country}

China has a profound, long history of excellent culture. The reason for the diversity of culture is that different cultures have different characteristics. However, from the cultural content in the materials, we can see that the native culture is obviously less than that of the Western culture, so the contents of the native culture should be written in the materials. It is conducive to develop China's excellent traditional culture and bring prosperity to world culture.

2. Improve communicative competence

"Cross-cultural communication occurs when cultural variations and differences affect the outcome of interpersonal 
communication." says Kari Dode. (cited from Dai Xiaodong, Theory of Intercultural Communication, 2011) Hu Wenzhong (1994) also emphasized that "Intercultural communicative competence refers to the ability to communicate effectively and appropriately with people from different cultural backgrounds". Therefore, we can conclude that improving communicative competence is the purpose of cultural content in materials.

3. Cultivate cultural awareness

The English Curriculum Standards (2011) also refers to "Cultivating students' sensitivity and adaptability to the English language, learning to understand and respect the cultures of other countries, and developing an open and critical culture of acceptance". Thus, we can stimulate the recognition and love of our society and culture, and really cultivate the comprehensive talents who can adapt to the process of globalization.

\section{Methodology}

\section{A. Research Questions}

Based on the analysis of the two sets of materials, this study attempts to answer the following two research questions.

(1) Which material is more in line with the requirements on the cultural awareness of the English Curriculum Standard for compulsory Education (2011)?

(2) What is the similarities and differences of students' cultural awareness using "Go for It" and "New Standard English”?

\section{B. Research Subjects}

In this paper, five volumes of "Go for It" in middle school written by the People Education Press cooperates with Thomson Learning Publishing Group and six volumes "New Standard English" in middle school written by Chen Linare cooperates with Ms. Printha Ellis and Ms. NaomiSimmons who are internationally renowned experts in this area.

With regard to participants in the process of questionnaire, 50 students in a middle school from Yanji and 50 students in a middle school from Changchun were investigated by questionnaire.

\section{Research Instruments}

The methods of literature, comparison and questionnaire are adopted to carry out the research.

Review of literature: By collecting different understandings of culture and the relevant literature of cultural content in the teaching materials.

Comparison: By comparing the cultural contents between two sets of materials, the author finds out the distribution and resources of the cultural content in two sets of materials and sums up the advantages and improvements of the two materials to judge which material is more in line with the requirements on the cultural awareness of the English Curriculum Standard for compulsory Education (2011).

Questionnaire: The questionnaire for students aims to investigate students' cultural awareness. This part contains 9 multiple questions which quoted a questionnaire from an article written by Li Jing "Cultural Teaching Analysis based on the Oxford English material of Shanghai High School (For students)". The author hands out 55 questionnaires to two different schools, a total of 110 and there are 100 valid answer sheets submitted.

\section{RESULTS AND DISCUSSIONS}

\section{A. Comparative Analysis of Two Materials}

With the aim to know whether or not the cultural content in the two sets of materials meet the requirements of the English Curriculum Standard for compulsory Education (2011), we can analyze it according to The goal of Cultural awareness grading (level 5). The results are shown in Table2 and Table 3.

According to the Grading Standard of Cultural awareness in the English Curriculum Standard for compulsory Education (2011), we can know the target culture includes eight aspects: 1. Body language (gesture or expression.) 2. Appellations, greetings, farewell words 3. Gender-specific names and affectionate address 4. Eating custom 5. Respond to compliments, requests, apologies 6. Express compliments, requests 7. Geography, climate, history 8. Interpersonal custom; International culture includes two aspects: 9. Culture, amusement and sports activities 10. Holidays and celebrations; Comparative culture includes 11. Similarities and differences; Native culture includes 12. Festivals and typical culture custom. 
TABLE 1.

THE GOAL OF CULTURAL AWARENESS GRADING

\begin{tabular}{ll}
\hline Level & \\
\hline & 1. Understand the body language commonly used in English communication, such as gestures, expressions, etc. \\
2. Make proper use of appellations, greetings and farewell words in English. \\
3. Understand and distinguish the common names and affectionate address of different genders in English. \\
4. Understand the eating customs of English-speaking countries. \\
5. Respond appropriately to the praise, request, apology. \\
6. Express praise, request, etc in an appropriate manner. \\
7. A preliminary understanding of the geographical location, climate characteristics and history of English-speaking countries. \\
8. Understand the interpersonal customs of English-speaking countries. \\
9. Learn about the main culture, amusement and sports activities in the world. \\
10. Learn about the main holidays and celebrations in the world. \\
11. Pay close attention to the similarities and differences of Chinese and foreign cultures, and deepen the understanding of Chinese \\
culture. \\
12. Introduce the main festivals and typical cultural customs of the motherland in English.
\end{tabular}

1. The distribution of cultural content

TABLE 2.

The Distribution Of CUltural CONTENT IN “Go For IT" AND "New STANDARD English" (CALCUlATED By THE FREQUENCY OF OCCURRENCE IN THE BOOK)

\begin{tabular}{|c|c|c|c|c|}
\hline \multirow{2}{*}{ Standard description } & \multicolumn{2}{|c|}{ "Go for It" } & \multicolumn{2}{|c|}{ "New Standard English" } \\
\hline & Total & Percentage & Total & Percentage \\
\hline 1. Body language (gesture or expression.) & 120 & $17.49 \%$ & 156 & $20.61 \%$ \\
\hline 2. Appellations, greetings and farewell words & 199 & $29 \%$ & 150 & $19.82 \%$ \\
\hline 3. Gender-specific names, affectionate address & 52 & $7.58 \%$ & 60 & $7.93 \%$ \\
\hline 4. Eating custom & 64 & $9.33 \%$ & 86 & $11.36 \%$ \\
\hline 5. Respond to praise, request, apology & 36 & $5.25 \%$ & 9 & $1.19 \%$ \\
\hline 6. Express praise, request & 93 & $13.56 \%$ & 20 & $2.64 \%$ \\
\hline 7. Geography, climate, history & 19 & $2.77 \%$ & 73 & $9.64 \%$ \\
\hline 8. Interpersonal custom & 4 & $0.58 \%$ & 10 & $1.32 \%$ \\
\hline 9. Amusement and sports activities & 63 & $9.18 \%$ & 149 & $19.68 \%$ \\
\hline 10. Holidays and celebrations & 14 & $2.04 \%$ & 18 & $2.38 \%$ \\
\hline 11. Similarities and differences & 13 & $1.90 \%$ & 18 & $2.38 \%$ \\
\hline 12. Festivals and typical culture customs & 9 & $1.31 \%$ & 8 & $1.06 \%$ \\
\hline Total & 686 & $100 \%$ & 757 & $100 \%$ \\
\hline
\end{tabular}

As we can see from Table 2, in terms of content distribution, the cultural content of the "New Standard English" is 757, "Go for It" is 686. "New Standard English" involves more cultural content than "Go for It".

We can find that if each item is close to $8 \%$, the distribution can be said to be balanced. But from the results, we can know that the distribution of each cultural content is unbalanced. For example, "Gender-specific names, affectionate address" in "Go for It" with 7.58\% and in "New Standard English" with 7.93\% are close to 8\%, "Eating custom" with 9.33\% and "Amusement and sports activities"with $9.18 \%$ in "Go for It" are close to $8 \%$, also "Geography, climate, history" with $9.64 \%$ are close to $8 \%$. Therefore, it can be said that the distribution of cultural content in the two materials are both very unbalanced. In particular, "Appellations, greetings and farewell words" in "Go for It" account for the largest proportion with $29 \%$ of the total cultural content. "Interpersonal custom" in "Go for It" account for the least proportion with $0.58 \%$ of the total cultural content.

2. The resource of cultural content

The target culture refers to the culture of the English-speaking country; native culture refers to the Chinese culture; international culture refers to the culture around the world.

TABLE 3.

THE SOURCE OF CULTURAL CONTENT IN “GO FOR IT" AND "NeW STANDARD ENGLiSh"

\begin{tabular}{|c|c|c|c|c|}
\hline \multirow[t]{2}{*}{ Classification } & \multicolumn{2}{|c|}{ "Go for It" } & \multicolumn{2}{|c|}{ "New Standard English" } \\
\hline & Total & Percentage & Total & Percentage \\
\hline Target culture & 587 & $85.57 \%$ & 564 & $74.50 \%$ \\
\hline International culture & 77 & $11.22 \%$ & 167 & $22.06 \%$ \\
\hline Comparative culture & 13 & $1.90 \%$ & 18 & $2.38 \%$ \\
\hline Native culture & 9 & $1.31 \%$ & 8 & $1.06 \%$ \\
\hline Total & 686 & $100 \%$ & 757 & $100 \%$ \\
\hline
\end{tabular}

From the Table 3, it can be concluded that in terms of content resources, the comparative culture and native culture of two sets of materials are similar. However, there is a gap between the content resource of the two materials in the target culture and international culture.

The content of target cultures with $85.57 \%$ in "Go for It" is obviously more than that in "New Standard English" with $74.50 \%$. However, the content of international cultures with $11.22 \%$ in "Go for $I t$ " is obviously less than that in "New Standard English" with $22.06 \%$. With regard to the content of comparative culture, the proportion in "New 
Standard English" is slightly higher than that in "Go for It", but there is no significant difference between the two materials in native culture. On the whole, the sources of cultural content in the two materials are not very balanced. In contrast, the source of cultural content in "New Standard English" is more balanced than that in "Go for It".

\section{B. Comparison of Students' Cultural Awareness Using “Go For It” And "New Standard English”}

The following questions are divided according to four dimensions.

TABLE 4.

RESUlTS OF THE QUESTIONNAIRE FOR STUDENTS IN “GO FOR IT” AND “NEW STANDARD ENGLISH”

\begin{tabular}{|c|c|c|c|c|c|c|c|c|}
\hline \multirow[t]{2}{*}{ Dimension } & \multicolumn{4}{|c|}{$\begin{array}{l}\text { "Go for It" } \\
\text { Percentage }\end{array}$} & \multicolumn{4}{|c|}{$\begin{array}{c}\text { "New Standard English" } \\
\text { Percentage }\end{array}$} \\
\hline & A & B & $\mathrm{C}$ & $\mathrm{D}$ & A & B & $\mathrm{C}$ & $\mathrm{D}$ \\
\hline \multirow{3}{*}{$\begin{array}{l}\text { 1. Students' knowledge, role and interest in cultural learning } \\
(\mathrm{Q} 1, \mathrm{Q} 3, \mathrm{Q} 7)\end{array}$} & 22 & 50 & 20 & 8 & 30 & 52 & 16 & 2 \\
\hline & 20 & 48 & 26 & 6 & 24 & 58 & 18 & 0 \\
\hline & 36 & 42 & 18 & 4 & 44 & 38 & 14 & 4 \\
\hline \multirow{2}{*}{ 2. The cultural teaching methods adopted by teachers (Q4,Q6) } & 32 & 38 & 26 & 4 & 38 & 40 & 20 & 2 \\
\hline & 38 & 24 & 32 & 6 & 44 & 24 & 32 & 2 \\
\hline \multirow{4}{*}{$\begin{array}{l}\text { 3. The ways to acquire English cultural knowledge for students (Q5) } \\
\text { 4. Students' attitude towards English classroom culture teaching } \\
(\mathrm{Q} 2, \mathrm{Q} 8, \mathrm{Q} 9)\end{array}$} & 44 & 34 & 14 & 8 & 34 & 40 & 14 & 12 \\
\hline & 38 & 42 & 20 & 0 & 42 & 42 & 14 & 2 \\
\hline & 12 & 40 & 38 & 10 & 28 & 32 & 36 & 4 \\
\hline & 48 & 30 & 20 & 2 & 58 & 30 & 10 & 2 \\
\hline
\end{tabular}

According to the Table4 listed above, about the dimension of "Students' knowledge, role and interest in Cultural Learning", students who use the "New Standard English", having a knowledge of cultural learning with $82 \%$, higher than who use the "Go for It" with $72 \%$; students who use the "New Standard English", affirming the importance of cultural awareness with $82 \%$, higher than who use the "Go for It" with $68 \%$; students who use the "New Standard English", showing their interest in cultural learning with $82 \%$, higher than who use the "Go for It" with 78\%.

About the dimension of "The Cultural teaching methods adopted by teachers", there is no significant difference between the teachers who use the "Go for It" and "New Standard English".

About the dimension of "The ways to acquire English cultural knowledge for students",there is no significant difference between the teachers who use the "Go for It" and "New Standard English". Most students acquire English cultural knowledge through English teaching materials and the teacher's explanation. There are 4\% more students acquire English cultural knowledge through the communication with foreigners.

About the dimension of "Students' attitude towards English classroom culture teaching", students who use the "New Standard English", generally having a higher level of cultural awareness than those who use the "Go for It". Students who use the "New Standard English", paying more attention to cultural learning with 84\%, Pershing than who use the "Go for It" with $80 \%$; Students' satisfaction with current English culture who use the "New Standard English" teaching is also $8 \%$ higher than those who use the "Go for It". Students' desire for strengthening the teaching of cultural content who use the "New Standard English" teaching is also $10 \%$ higher than those who use the "Go for It".

\section{CONCLUSION}

This paper uses comparison to know whether or not the cultural content in the two sets of materials meet the requirements of the English Curriculum Standard for compulsory Education (2011). It was found that the teaching materials of "New Standard English" were more in line with the requirements of the curriculum standards than those in the "Go for It".

The study uses the questionnaire to know the similarities and differences of cultural awareness of students using different materials. Through the investigation, it is found that the students who use the "New Standard English" pay more attention to the cultural knowledge and teaching than the students who use the "Go for It", and are willing to absorb the British and American culture, therefore students who use the "New Standard English", having higher cultural awareness.

\section{SUGGESTIONS}

Teachers should pay more attention to the teaching of cultural content so as to make students interested in cultural knowledge and thus enhance their cultural awareness. At the same time, from the investigation, we also found that teachers seldom talk about the different content between Chinese and foreign cultures in class. Teachers should establish a cross-cultural perspective so as to enhance students' cultural awareness to Chinese and Western cultures through cultural comparison, and help students to understand their own and other cultures.

Students should try their best to learn cultural content in class and extracurricular reading, master cultural knowledge to improve communication ability. And then they should understand the comparison between Chinese and Western countries to spread Chinese excellent culture, and then cultivate cultural awareness. 
Authors can introduce less content about "Appellations, greetings and farewell words" in "Go for It" which account for the largest proportion with $29 \%$ of the total cultural content and more content about "Interpersonal custom" in "Go for It" which account for the least proportion with $0.58 \%$ of the total cultural content. And then authors can introduce more knowledge of comparative culture and native culture to achieve a balanced distribution of cultural content.

\section{APPENDIX}

\section{亲爱的同学们:}

你们好！为了更好的了解同学们的跨文化意识以及对于文化意识和文化教学的态度，从而帮助我们更好地 完善在英语教材的基础上进行文化教学, 特设计此问卷。此次调查的结果仅仅用于学术研究, 没有任何商业目 的。为尊重您的隐私, 此问卷调查采取匿名的方式, 希望同学们根据自己的实际情况和个人看法真实作答。请 同学们直接把选择的选项进行标记, 并且最后按题号填入答案框中。

十分感谢你们的支持与合作!

您使用的教材：人教版，外研版（打钩）

1. 你认为文化意识在英语教学中重要吗?（）

A. 非常重要, 文化意识对英语教学有很大帮助。

B. 很重要, 但考试涉及不多, 所以不够重视。

C. 一般, 没太大帮助。

D. 完全没用。

2. 你重视对英语文化的学习吗？（）

A. 很重视, 我会经常去了解英语国家文化。

B. 一般, 偶尔会了解一下。

C. 不太关心，因为考试涉及得不多。

D. 完全不重视, 没有必要去学习文化。

3. 你对英语国家的社会历史文化、风俗习惯的了解程度如何？（）

A. 非常了解。

B. 比较了解。

C. 了解不多。

D. 完全不了解。

4. 你的英语教师会教授英语国家文化吗？（）

A. 经常, 老师经常会普及英语国家文化, 很生动实用。

B. 有时候会教授教材中涉及的文化内容。

C. 偶尔会提及, 但次数很少。

D. 从来没有。

5. 你主要是通过哪些途径了解英语国家文化? ( )

A. 英语教材。

B. 老师上课的讲解。

C. 通过互联网、课外书籍、影视等等。

D. 与外国人的交流。

6. 你的英语教师在渗透文化教学时主要是通过哪些方式?（）

A. 通过对上课教材内容的讲解。

B. 专题讲座。

C. 让学生自行课外了解文化。

D. 其他

7. 你对教材上关于介绍英语国家的文化感兴趣吗?（）

A. 非常感兴趣。

B. 一般。

C. 不太感兴趣。

D. 完全不感兴趣。

8. 大体来说, 你对当前初中英语的文化教学满意吗? （）

A. 非常满意。

B. 比较满意。

C. 不太满意。

D. 非常不满。

9. 你觉得是否应该加强对文化内容的教学力度? ( ) 

A. 很有必要。
B. 看老师的安排。
C. 可以适当增加一些内容, 多学习总是好的。
D. 没有必要。

\section{ACKNOWLEDGMENTS}

First of all, I would like to thank my supervisor, Professor Xuebo Cui, who not only cares about my theoretical study, but also provides me valuable suggestions. Thanks for professor's patient guidance, so that I can make progress in research, teaching practice and so on.

Then, I also want to express my gratitude to all the professors at the Foreign Language Institute. With their devoted teaching and enlightening lectures, I have benefited a lot.

Finally, I am thankful to friends and my dear parents. Thank you very much for supporting me and providing all kinds of help, it is my biggest motivation.

\section{REFERENCES}

[1] Cheng Xiaotang. (2002). Analysis and Design of English Teaching Materials. Beijing: Foreign Language Teaching and Research Press.

[2] Dörnyei, Z. (2011). Questionnaires in Second Language Research: Construction, Administration and Processing. Beijing: Foreign Language Teaching and Research Press.

[3] Hu Wenzhong. (1994). Culture and communication. Beijing: Foreign Language Teaching and Research Press.

[4] Hu Yaping. (2018). The Study of Chinese Culture Integration in NSEFC Based on NECS. Master's thesis, East China University of Technology.

[5] Lee, Kang-young. (2009). Treating culture: what 11 high school EFL conversation textbooks in South Korea do. English Teaching: Practice and Critique, 8, 76-96.

[6] Li Ye. (2016). An Evaluation of the Cultural Contents to PEP New Senior English for China from the Intercultural Perspective. Master's thesis, Guangxi Normal University.

[7] Lin Zu, Kong Zheqiong. (2009). A study on the approaches to culture introduction in English textbooks. English Language Teaching, 1, 112-118.

[8] Ministry of Education. (2011). English Curriculum Standard for compulsory Education. Beijing: People's Education Press.

[9] Pi Tiantian. (2017). A Comparative Study on the Cultural Content in Project English and Go For It. Master's thesis, School of Foreign Languages Central China Normal University.

[10] Qin Xidi. (2015). The Cultural Composition of English material in Primary School and Its Embodiment in the Teaching. Master's thesis, Qingdao University.

[11] Seelye, N. (1994). Teaching Culture:Strategies for International Communication. Lincolnwood: National Textbook Company Publishing Group.

[12] Stern, H. (1998). Issues and Options in Language Teaching. Oxford: Oxford University Press.

[13] Tylor, E.B. (1871). Primitive Culture: Researches into the Development of Mythology, Philosophy, Religion, Language, Art and Custom. London: John Murray.

[14] Tomlinson, B. (1998). Materials Development in Language Teaching. Cambridge: Cambridge University Press.

[15] Tomlinson, B \& Hitomi Masuhara. (2007). Developing language Course Materials. Beijing: People's Education Press.

[16] Wei Handi. (2016). Problems and Countermeasures in the Process of Intercultural English Teaching in Middle School. Master's thesis, Hainan Normal University.

[17] Wang Fei. (2010). Cultural Choice and allocation in College English textbooks in China: a case study of two sets of College English "Comprehensive courses". Journal of Xi'an University of Foreign Studies, 2, 104-108.

[18] Wu Wenling. (2013). Cultural contrast and teaching research of senior high school English teaching material "Go for it". Master's thesis, Shanxi Normal University.

[19] Zhao Feifei. (2015). An Analysis of the Cultural orientation in Middle School English textbooks. Survey of Education, 20, 49-51.

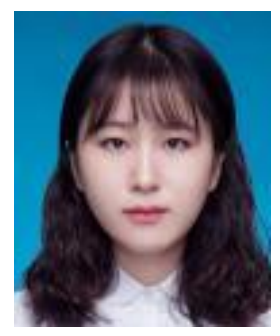

Yujie Shi, born in Jilin Province, China in 1994. She is an M.A. student majoring in English education in Yanbian University 
Xuebo Cui is the corresponding author. She was born in Yanji, China. She received PH.D. degree in Applied Linguistics from De La Salle University, Manila in the Philippines in 2004.

She is currently an associate professor in English Department, Yanbian University, China. Her research interests include curriculum design and development, professional development for teachers of English, bilingual education, and contrastive linguistics. 